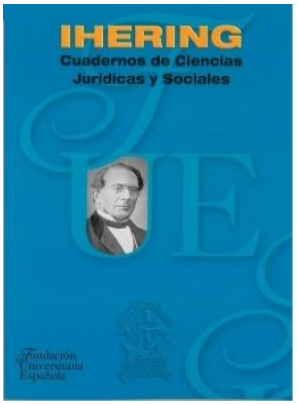

(cc) (i)
Ihering. Cuadernos de Ciencias Jurídicas y Sociales N. 04

Año: 2021

Publicación del SEMINARIO DE ESTUDIOS EUROPEOS "DIEGO DE MENDOZA" de la Fundación Universitaria Española e-ISSN: 2660-552X DOI: https://doi.org/10.51743/ihering.213 Recibido: 13-07-2021 | Revisado: 30-09-2021 Aceptado: 18-10-2021 | Publicado: 23-12-2021

\title{
THE PROBLEM OF DEFINING STAKEHOLDERS IN A SUSTAINABLE DEVELOPMENT GOAL CONTEXT, EXAMINED VIA THE ANALYSIS OF ENVIRONMENTAL CONSERVATION
}

\footnotetext{
EL PROBLEMA DE LA DEFINICIÓN DE LOS INTERESADOS EN UN CONTEXTO DE OBJETIVOS DE DESARROLLO SOSTENIBLE, EXAMINADO A TRAVÉS DEL ANÁLISIS DE PROYECTOS DE CONSERVACIÓN AMBIENTAL.
}

\section{Elena Bulmer}

https://orcid.org/0000-0001-6686-5849

Universidad Rey Juan Carlos (Madrid)

EAE Business School (Madrid) 


\begin{abstract}
There has been to date only limited consideration within the project management discipline of nonhuman actors as primordial stakeholders in projects. However, the inclusion of the roles of nonhuman actors is essential, when we consider that many projects in many areas, both within and outside the field of environmental conservation itself, such as for example in the fields of business and management, depend on natural resources for the development of their products. Despite this, natural resources tend to be overlooked in the stakeholder maps of projects in this wider context. Environmental Conservation projects are themselves especially interesting to study with regards to their stakeholder context and have been used as the experimental setting for the empirical work of this study. The primordial stakeholders of these projects are not social objects and therefore go beyond what are currently generally regarded as the limits of stakeholder theory. The study that has been used to analyse this concept is a marine conservation project based in Spain, whose primordial actor is not human. Unfortunately, these stakeholders being non-human are therefore not able to express themselves, and therefore are rarely purposely included in stakeholder analysis and management approaches, thus limiting comprehensive stakeholder mapping analyses ab initio, and handicapping realistic consideration of nonhuman actors. This study may be extrapolated and applied to the United Nation's Sustainable Development Goal (SDG) 17, "Partnership for the goals", with reference to SDG 14, which deals with marine conservation.
\end{abstract}

Keywords- Conservation project, Non-human actor, Project management, Project stakeholder, Sustainable Development Goal, Sustainability, Sustainable Development Goal 17

Attribution-NonCommercial 4.0 International (CC BY-NC 4.0). e-ISSN: 2660-552X 


\section{Resumen}

Hasta hoy, no se había tenido en consideración a los actores no humanos dentro de la disciplina de gestión de proyectos. Sin embargo, la inclusión de estos tipos de partes interesadas es fundamental cuando implementamos, por ejemplo, proyectos en el ámbito de la conservación medioambiental o en el mundo corporativo que dependen de recursos naturales para el core de su negocio y el desarrollo de sus productos. A pesar de esto, los recursos naturales tienden a pasarse por alto en los mapas de interesados de los proyectos.

En este estudio, se usaron los proyectos de conservación de la naturaleza para investigar el contexto de las partes interesadas no humanas. Los actores primordiales de estos proyectos no son objetos sociales y, por lo tanto, van más allá de lo que en la actualidad se considera generalmente como los límites de la teoría de interesados en el mundo de la dirección de proyectos. El estudio en cuestión de este caso se ubica en Valencia (España), y se ocupa de la conservación de tortugas marinas, que son los actores primordiales del proyecto. Desafortunadamente, las tortugas son actores que no pueden expresarse y, por lo tanto, rara vez son incluidas en los análisis de partes interesadas. Este estudio puede extrapolarse y aplicarse al Objetivo de Desarrollo Sostenible (ODS) 17 de las Naciones Unidas, "Asociación para los objetivos", y hace referencia específica al ODS 14, que trata sobre la conservación marina. para los objetivos", y hace referencia específica al ODS 14, que trata sobre la conservación marina.

Palabras clave: Proyecto de conservación, Actor no humano, Gestión del proyecto, Parte interesada, Objetivo de Desarrollo Sostenible, Sostenibilidad, Objetivo de Desarrollo Sostenible 17 


\section{INTRODUCTION}

The Millennium Development Goals (MDGs) were developed by the United Nations at the Millennium Summit in September 2000. Eight goals were developed in order to set up social global timebound and attainable objectives to be complied with and achieved by the year $2015^{53}$. At the end of those fifteen years, there was widespread feeling among different stakeholders such as policy makers and civil society that "progress against poverty, hunger and disease (was) notable; (and) that the MDGs (had) played an important part in securing (this) progress and that globally agreed goals to fight poverty should continue beyond 2015"54. Consequently, world governments decided to continue and to develop a new set of global priorities that are today known as the Sustainable Development Goals (SDGs).

The United Nations (UN) Conference on Sustainable Development, also known as Rio+20, was held in Rio de Janeiro (Brazil) between June 20th and June 22nd, 2012. The main objective of this summit was to create planetary goals that would resolve global environmental, social and economic challenges. Rio+20 marked the launch point for the creation of the Sustainable Development Goals (SDGs), also known today as the "Agenda 2030 for Sustainable Development". The seventeen SDGs were an urgent call for action by all countries to create a global partnership to put an end to global problems such as poverty and inequalities, besides improving health and education, all while working to preserve our planet.

The seventeenth SDG titled, "Revitalize the global partnership for sustainable development", entails the creation of inclusive partnerships at all levels (i.e., global, regional, national and local) to successfully attain the rest of the sixteen goals. At present, such stakeholder collaboration is needed more than ever to ensure that countries have the means to recover from the Covid 19 pandemic and attain the SDGs. This is especially so for developing countries that have been struck harder

\footnotetext{
${ }^{53}$ United Nations (2021 March 1). 17 Goals to Transform our World. https://www.un.org/sustainabledevelopment/

${ }^{54}$ Sach, JD. From Millennium Development Goals to Sustainable Development Goals. The Lancet, 2012; 379 (9832): 2006-2211.
}

Attribution-NonCommercial 4.0 International

(CC BY-NC 4.0).

e-ISSN: $2660-552 X$ 
than developed countries due to the lack of healthcare facilities and means. Inclusive partnerships should therefore be promoted between different stakeholders at all levels, such as between private companies, NGOs and local and national authorities, as well as civil society. These partnerships should be built upon a shared vision and shared goals having people and the planet at their centre.

The United Nations (UN) Intergovernmental Panel on Climate Change has highlighted the urgency to find project solutions to these global challenges. At present, there do not appear to be the tools, methods, leadership or propitious business-society environment at the project level to attain meaningful Sustainable Development Goal success. This may well therefore lead to a potential knowledge gap, in relation to the SDGs, in learning reliable lessons from successes or failures in project delivery. Project managers therefore find themselves at the "grass-root" level in this regard and a grand challenge lies ahead in the SDG context.

The Project Management Institute in its most recent version of the PMBOK, the Project Management Book of Knowledge ${ }^{55}$, describes project management as embracing ten knowledge areas: Integration, Scope, Schedule, Cost, Quality, Resource, Communication, Risk, Procurement and Stakeholder Management. In the SDG 17 context, stakeholder management is of special relevance and will be the knowledge area that will be analysed in more detail in this study.

In this article, a brief theoretical background will firstly be presented regarding stakeholder management. Secondly, the hypothesis will be presented regarding whether the existing project stakeholder management theory that only takes into account human beings may be extended to include non-human stakeholders. This "extended" version of the definition of a project stakeholder may prove beneficial in SDG contexts and provide a more global perspective, especially for those SDGs that entail the protection of specific natural resources, such as SDG 14 "Life under water" and SDG 15 "Life on land". This article analyses this hypothesis in an SDG 14

55 PMI, 2017

Ihering. Cuadernos de Ciencias Jurídicas y Sociales N. 4 (2021)

DOI: https://doi.org/10.51743/ihering.213 
context using a marine turtle conservation project as the basis of the empirical study of this study.

\section{THEORETICAL FRAMEWORK: STAKEHOLDERS AND THE POTENTIAL INCLUSION OF NONHUMAN ACTORS IN PROJECTS TO ATTAIN THE SDGS.}

Stakeholder management is a topic in which research interest has been gaining momentum since $2005^{56}$ although early research dates back to the early $1960 \mathrm{~s}^{57}$. A stakeholder in an organization is defined as "any group or individual who can affect or be affected by the achievement of the organization's objectives" 58 . The connotation by which the stakeholders can be affected by or can affect a project may be either positive or negative. What is very important however, is for all these stakeholders to be identified, prioritised (with regards to their power and influence in the project) and mapped in what is known as a stakeholder map. The stakeholders themselves may be either or both internal or external to the project ${ }^{59}$.

It is interesting to mention at this point in the discussion, the concept of project stakeholder complexity. Project stakeholder complexity can stem from, for example, project size such as in megaprojects, where the number of stakeholders is very large, or from the difficulty there may be in determining the position of the specific stakeholders within the project. Deciding whether they are for or against the project (when they could be both) is often difficult in some project scenarios. A further point that may contribute to the complexity of the stakeholder management panorama is

\footnotetext{
${ }^{56}$ Winch, G. (2016). "Megaproject Stakeholder Management" in The Oxford Handbook of Mega-project Management (Ed. Bent Flyvbjerg). Oxford: Oxford University Press

${ }^{57}$ Freeman, R.E. (1984). Strategic Management: A Stakeholder Approach. Cambridge, CUP.

58 (Freeman 1984)

${ }^{59}$ Winch, G. (2010). Managing construction projects. Blackwell Publishing Ltd. lowa, USA.
}

Attribution-NonCommercial 4.0 International

(CC BY-NC 4.0).

e-ISSN: 2660-552X 
the potential identification and inclusion of stakeholders who may not normally be considered to be part thereof (i.e., but who nevertheless do have a strong protagonist role in the project; such may be the case for nonhuman actors, ranging from mountains to natural resources. In this respect, it is not easy to deal with nonhuman actors as they are not able to express themselves and therefore not able to communicate with us whether they are for or against the project.

There are many authors who argue against the inclusion of nonhuman actors in the stakeholder map of projects. An example of such a nonhuman actor is the natural environment (i.e., natural resources) on which so many corporations and companies depend for the conception and development of their projects ${ }^{60}$. The question here is whether the natural environment should be a project stakeholder (i.e., and in many cases a primordial project stakeholder). "This is a radical extension to Freeman's definition above, yet the natural environment is both clearly affected by (e.g., pollution, global warming) and affects (e.g., depletion of exploitable natural resources; natural disasters) the corporation in the pursuit of its project and business objectives ${ }^{61}$.

However, there is still some reluctance from academics to agree with the above ${ }^{62}$. Driscoll and Starik (2004: 55) argue that "while most stakeholder theories have progressed to the point in which the natural environment is given stakeholder status, some academics continue to be reluctant to include the natural environment as one of the...primary stakeholders". Further reluctance has been demonstrated by corporations that tend to overlook the importance of the environment as a

60 Driscoll, C. \& Starik, M. (2004). The Primordial Stakeholder: Advancing the Conceptual Consideration of Stakeholder Status for the Natural Environment. Journal of Business Ethics, 49:55-73.

${ }^{61}$ (Winch 2016)

${ }^{62}$ (Driscoll and Starik 2004) 
stakeholder and consequently place it low on the stakeholder list ${ }^{63} 6465$. Other researchers seem to think that the global economic system and the environment are dissociated and independent of one another ${ }^{666768}$. This last assertion is made independently of whether the environment is or is not the project's primordial stakeholder. The same divergence of views is also very much apparent at the practitioner level. However, the existence of a mutually dependent relationship between the environment and business organizations has been identified ${ }^{69}$. Failure to include the natural environment as a project stakeholder may often lead to considerable monetary losses, as for example for an agriculture-based business should there be a serious drought or where the depletion of fish in the fishing industry may lead to serious financial losses ${ }^{70}$. After all, firms do depend on local ecosystems (i.e., raw materials) for their survival and the development of their products ${ }^{7172}$.

In addition to avoiding or reducing monetary losses, the inclusion of these primordial stakeholders in the project stakeholder map will also promote their conservation. An example of this is a river otter case study in Missouri, USA. In this example,

${ }^{63}$ Bendheim, C.L., Waddock, S.A. \& Graves, S.B. (1998). Determining Best Practice in Corporate Stakeholder Relations Using Data, Envelopment Analysis. Business and Society 37(3), 306-448.

64 (Driscoll and Starik 2004)

65 Nasi, J., Nasi, S., Philips, N. \& Zyglidopoulos, S. (1993). "What is Stakeholder Thinking? A Snapshot of a Social Theory of the Firm", in J. Nasi (ed), Understanding Stakeholder Thinking. Helsinki, LSR-Julkaisut Oy, 19-32.

66 Gladwin, T.N., Kennelly, J.K. \& Krause, T.S. (1995). Shifting Paradigms for Sustainable Development: Implications for Management Theory and Practice.

${ }^{67}$ (Driscoll and Starik 2004)

68 Stead, J.C. \& Stead, W.E. (2000). Ecoenterprise Strategy: Standing for Sustainability. Journal of Business Ethics, 24(4): 313-329.

${ }^{69}$ (Driscoll and Starik 2004)

70 (Driscoll and Starik 2004)

71 Gladwin, T.N., Kennelly, J.K. \& Krause, T.S. (1995). Shifting Paradigms for Sustainable Development: Implications for Management Theory and Practice. Academy of Management Review, 20(4): 874-907.

72 (Driscoll and Starik 2004)

Attribution-NonCommercial 4.0 International

(CC BY-NC 4.0).

e-ISSN: 2660-552X 
Missouri's Department of Conservation (DOC) wanted to reintroduce the river otter and did so; however, as the species began reproducing, conflicts started to arise between the DOC, the local residents, the animal activists and the scientists ${ }^{73}$. As nonhuman primordial stakeholders, the river otters in this project were not able to express themselves so as to have their say in the project. Their inclusion in the project as primordial stakeholders was key for the project to achieve a successful outcome. This kind of case study thus raises the question as to how these nonhuman environmental stakeholders may be taken into account and represented in a project. For these stakeholders, the "stakes are only relevant when they are inserted into a process where they influence the courses of action in the project"74.

An example of a study in which nonhuman actors, in this case scallops, were given conceptual equality to the human actors (fishermen and researchers) is provided by Callon who analysed how researchers were trying to regenerate the scallop industry at St Brieuc Bay in France, in order that the fishermen could still make a profit from their trade. In this case study, it is interesting to note that the scallops were the project's primordial stakeholders and how we can observe a process of translation, where the scallops are translated into larvae, the larvae into numbers, the numbers into tables, etc. ${ }^{75}$.

Both of these studies may be translated to a number of other and different scenarios that involve the relationship between human actors and the natural world (fauna, flora, ecosystems etc.) in other project types, such as construction projects and

${ }^{73}$ Goedeke, T.L. \& Rikoon, S. (2008). Scientific Controversy, Dynamism of Networks, and the implications of Power in Ecological Restoration. Social Studies of Science 38(1): 111-132.

${ }^{74}$ Tryggestad, K., Justesen, L. \& J. Mouritsen. (2013). Project temporalities: how frogs can become stakeholders. International Journal of Managing Projects in Business 6(1): 69-87

${ }^{75}$ Callon, M. Some elements of a sociology translation: domestication of the scallops and fishermen of St Brieuc Bay". In: Law, J. Power, Action and Belief: A New Sociology of Knowledge. London, United Kingdom: Routledge \& Kegan Paul; 1986. pp. 277-303 
engineering projects, where the environment is an important or primordial stakeholder. Many types of business organizations have a mutual dependency with the environment, however at present this is simply not recognized as being so ${ }^{76}$.

To date the identification and planning of stakeholder participation in projects has involved the use of qualitative methods. The PMBOK's definition of a stakeholder is very much aligned with that of Freeman as "an individual, group, or organization that may affect, be affected by, or perceive itself to be affected by a decision, activity, or outcome of a project, program, or portfolio" (PMI, 2017); however, the methods used are only applicable to human subjects and not to nonhuman collectives or subjects. This is particularly relevant when we analyse for example, the Power/Interest grid of stakeholders, where, depending on the positioning of a particular stakeholder, it is possible to determine how best to treat them in the future, such as keeping them satisfied, informed, etc. (PMI, 2017). This conventional method of treating stakeholders used at the project planning stage is of limited applicability to nonhuman subjects, and therefore an alternative solution is needed. This is especially the case when the primordial project stakeholder is, for example, a nonhuman environmental stakeholder. A possibility here would therefore be to have a human subject represent the nonhuman project stakeholder.

In this article the inclusion of nonhuman actors will be analysed through the evaluation of environmental conservation (EC) projects. Most EC projects have a rather complex stakeholder panorama. Firstly, the final beneficiary or customer of these projects, which is very often their primordial stakeholder, is not fully defined, and therefore it will be arduous to determine how the project will be able to best benefit these primordial stakeholders and thereby to determine the benefits realization of these projects. If the primordial stakeholders are not properly accounted for, then it is very difficult to determine what project objectives and methods will best benefit them. Secondly, the primordial stakeholders of these projects, tending to be nonhuman (fauna, flora and ecosystems), are often neglected

${ }^{76}$ (Driscoll and Starik 2004)

Attribution-NonCommercial 4.0 International

(CC BY-NC 4.0).

e-ISSN: 2660-552X 
and not properly managed in these projects. Thirdly, the wide range of human and nonhuman stakeholders (stakeholder multiplicity) with multiple interests can lead to eventual conflicts. This complex stakeholder panorama is evidenced, for example, in the river otter case study in Missouri, USA 77 and the Moor frog case study (although in the latter study the Moor frog was a secondary stakeholder) ${ }^{78}$.

The study being analysed in this article is a marine turtle bycatch project based in the Valencian Community of Spain, located along the Mediterranean coast on the east side of the Iberian Peninsula, where the primordial stakeholder is the marine turtle. Marine turtles are animal species that are threatened worldwide. At present all seven species of marine turtle are classified as threatened species by the International Union for the Conservation of Nature (IUCN), one of the largest conservation organizations in the world and represented in almost every country. The IUCN strives to provide "public, private and non-governmental organisations with the knowledge and tools that enable human progress, economic development and nature conservation to take place together" 79 .

The marine turtles are presently threatened by five main hazards which are all anthropogenic. Amongst these are the (i) impact of fishing, (ii) direct take, (iii) coastal development, (iv) pollution and pathogens, and (v) global warming. These elements not only affect sea turtles but also many other marine fauna and flora. Unlike hazards affecting terrestrial habitats, marine threats are not geographically bound, as all marine environments connect to each other, and thereby all marine fauna and flora are affected equally by them on a global basis. A recent example of this is the

\footnotetext{
77 (Goedeke and Rikoon 2008)

78 Tryggestad, K., Justesen, L. \& J. Mouritsen. (2013). Project temporalities: how frogs can become stakeholders. International Journal of Managing Projects in Business 6(1): 69-87.

79 IUCN. About International Union for Conservation of Nature. Available from: https://www.iucn.org/about (Accessed on 1 March 2021)
} 
problem with marine plastic debris. A plastic bottle may be thrown into the Mediterranean Sea and end up in Latin America. Malpractice in waste management in a specific geographic area may therefore affect marine turtles everywhere as marine turtles are similarly not geographically bound and are affected everywhere by this now global problem. Sea turtles are presently globally distributed and are often present in the Atlantic, Pacific, and Indian oceans, as well as in the Mediterranean Sea, therefore the plastic problem is bound to affect them anywhere in some way or other.

Projects that are set in the marine environment pose challenges that go beyond national boundaries. It is for this reason that resolution of such large-scale environmental challenges has had to involve a realm of different actors, comprising not only governments (national and regional), but also non-state actors such as nongovernmental organizations and private companies. Although a multi-actor partnership context may seem ideal to resolve these environmental issues as suggested by Sustainable Development Goal 17 and the 2030 Agenda Accelerator, it might entail conflicts of governance concerning different spheres of authority, especially when the project mission involves a nonhuman primordial actor. Furthermore, the inclusion of this non-human primordial actor in the project stakeholder map may be a way forward in the pursuit of more targeted solutions.

This article will explore the stakeholder context of a marine turtle conservation project via the inclusion of the marine turtle as a project actor in the stakeholder analyses, using a series of conventional project stakeholder analysis tools (i.e., which later be described in the Research Methodology section). In the results and discussion section, the outcome of the different analyses (i.e., stakeholder register, PI matrices and stakeholder map) will firstly be presented as well as then the general trends that were extracted from the narratives that were developed for this study. 


\section{RESEARCH METHODOLOGY}

A case study approach was undertaken for the data collection using desk-based research and semi-structured interviews. The case study analysed was a sea turtle conservation project based in the Valencian Community in Spain. The objective of this project was to reduce sea turtle bycatch off the Levante Coast.

This case study presents a very revealing stakeholder situation, where we see that there are conflicting interests among conservationists, fishermen, municipality representatives and others. The stakeholders interviewed are listed below:

- Project Holding organization: "Asociación Chelonia" is a Spanish conservation NGO based in Madrid that possesses over twenty years of experience in the world of marine conservation in the Iberian Peninsula. For this study, several of the organization's members were interviewed.

- Other NGOs: the other NGOs included in this analysis, include "Xaloc", which is a marine conservation organization based in Valencia, and "CEMMA", a conservation organization based in Galicia.

- Funders: the project funders include the American Fish and Wildlife Service (FWS), and the Spanish "Fundación Biodiversidad"

- State government: The General Secretariat of Fishing has a mandate from the Environment Ministry to develop the European Union's fisheries policy.

- Local government: Represented by a technical specialist from the Environmental Department of the Generalitat (regional government of the Valencian Community)

- Fishermen: Only a representative of the local Gandía fishermen's association was interviewed.

- Civil society 
The interview process was performed between October 2018 and October 2019. In total, 21 different stakeholders were interviewed. Among the interviewees were public officials with environmental responsibilities, fishermen's associations, NGOs and university professors. The interviews were performed in Spanish, transcribed (i.e., in Spanish) and subsequently analysed to enable the development of narratives.

The 21 semi-structured interview questions related to (1) the context and professional background of the interviewee, (2) their knowledge of each of the case studies being analysed, (3) their knowledge of project stakeholder analyses, (4) their perception of the marine species being conserved (i.e., the marine turtle), and (5) their definitions of the terms power and interest, along with a small power-interest matrix exercise through which interviewees had to value the level of power and interest of the following stakeholder groups with respects to the project's mission. All interviews were transcribed in Spanish, and the narratives were then developed in English.

The stakeholder analyses were based firstly on the development of a stakeholder register (Table 1), which encompassed:

- Stakeholder identification information

- Stakeholder classification information (i.e., main expectations regarding the project, whether stakeholders were internal/external to the project, and whether they were supporters, opponents or neutral.

- Problems experienced by interviewed stakeholders.

- Solutions to identified problems. 
Based on the information included in the stakeholder register, a stakeholder map ${ }^{80}$ was developed. According to Callon ${ }^{8182}$ the definitions and role of a stakeholder in a project cannot be separated from their relationships ${ }^{83}$. Therefore, the conception of a stakeholder mapping exercise to better understand the project stakeholder relationships proved more than essential. Based on the information gathered in the stakeholder register a stakeholder map was conceived using the 2002 Bonke and Winch stakeholder mapping model. In this framework (Figure 1), the central asset is the project mission, and the identified stakeholders are positioned around it. Their position in the project is identified as being a proponent or opponent as well as the potential problems that may be experienced. In this map the marine turtle was not included as they were obviously not capable of being interviewed.

To complement these analyses, Power-Interest (PI) matrices were also developed to compile the PI matrix information collected in the different interviews. This tool enables the categorization of stakeholders according to their level of power and interest in the project. For the PI Matrix analyses, the stakeholders included in the PI matrices were grouped according to the stakeholder categories listed above. The exercise was carried out to include the perceptions that different project stakeholders had of the role (i.e., power of level and interest) of the marine turtle in the project. This is shown in Figure 3.

The results from the stakeholder register, PI matrices and stakeholder map, were further analysed via the development of narratives. Organizational narratives are

80 IUCN. About International Union for Conservation of Nature. Available from: https://www.iucn.org/about (Accessed on 1 March 2021)

${ }^{81}$ (Callon 1986)

${ }^{82}$ Callon, M., Latour, B. Unscrewing the big Levathan: how actors macrostructure reality and how sociologists help them to do so. In: Knorr-Cetina, K., Cicourel, V. Advances in social theory and methodology: towards an integration of micro- and macro- sociologies. Boston, United States: Routledge \& Kegan Paul; 1981.

${ }^{83}$ Missioner, S., Loufrani-Fedida, S. Stakeholder analysis and engagement in projects: From stakeholder relational perspective to stakeholder relational ontology. International Journal of Project Management, 2014; 32: 1108-1122. 
temporal in nature and are defined as being "discursive constructions that provide a means for individual, social and organizational sensemaking and sense giving". This sense of temporality is very adequate to this research for several different reasons: firstly, the nature of a project is temporal as a project needs to be completed in a defined space of time, and secondly, the stakeholder associations and networks that are created throughout the project's progress are temporary; they will be created, and after some time disassociate or change. Furthermore, organizational narratives helped to analyse the interplay between all the project stakeholders, making therefore plausible the development of multiple narrative analyses. In the results and discussion section, the outcome of the different analyses (i.e., stakeholder register, PI matrices and stakeholder map) will firstly be presented as well as the general trends that were extracted from the narratives that were developed for this study.

\section{RESULTS}

The marine turtle case study analysed, aimed at reducing bycatch rates by Spanish fishing fleets with a pilot study on the use of Turtle Excluding Devices (TEDs) in Calpe, on the coasts of Valencia. Twenty-one project stakeholders were interviewed. The only two stakeholders' groups that were not interviewed were the recreational fishermen and the civil society members.

From the interview information, a stakeholder register was developed as shown below (Table 1). For each of the identified stakeholders, his/her identification details were recorded, together with their main expectations, and problems they may have experienced with respect to the project mission, as well potential solutions to these problems. It is important to note here that the marine turtle was not included in this table as it was not interviewed as such.

Attribution-NonCommercial 4.0 International

(CC BY-NC 4.0).

e-ISSN: 2660-552X 
Table 1: Stakeholder register of marine turtle bycatch project

\begin{tabular}{|c|c|c|c|c|c|c|c|c|c|}
\hline & \multirow[b]{2}{*}{ Postion } & \multirow[b]{2}{*}{ Organzzation / Company } & \multirow[b]{2}{*}{ Location } & \multirow[b]{2}{*}{ Role in Prgect } & \multicolumn{3}{|c|}{ Stakeh older Classification } & \multirow{2}{*}{\begin{tabular}{|l} 
Problems experien oed by these stakehoiders \\
Problems expenienced by these stakchidders \\
\end{tabular}} & \multirow{2}{*}{$\begin{array}{l}\text { Solutions to the se problems } \\
\text { Sdufions to these prodiems }\end{array}$} \\
\hline & & & & & Main Expectations & $\begin{array}{l}\text { Internal } \\
\text { Eiterna }\end{array}$ & $\begin{array}{l}\text { Defender I } \\
\text { Neutal I } \\
\text { Opponent }\end{array}$ & & \\
\hline 1 & $\begin{array}{l}\text { Director of Chelonia } \\
\text { Colombia }\end{array}$ & Chelonia & Madrid & Project member & $\begin{array}{l}\text { The successful erecution and testing of } \\
\text { TED device, as wetl as the successful } \\
\text { completion of the project. }\end{array}$ & Internal & Defender & Desing with the fishermen, getting orboard the ship. & $\begin{array}{l}\text { Greater degree of communication ensuring that their role of the } \\
\text { isthermen is taken irto account }\end{array}$ \\
\hline 2 & President of NGO & Chelonia & Madrid & Project lead & 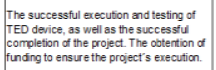 & Internal & Defender & $\begin{array}{l}\text { Getting funding for the project deaing with the } \\
\text { defferent statecholders and ensuring project } \\
\text { completion }\end{array}$ & 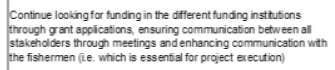 \\
\hline 3 & Projects director & Chelonia & Galicia & Project management & $\begin{array}{l}\text { The successful execution and testing of } \\
\text { TED derice, as well as the successtul } \\
\text { complefion of the project. }\end{array}$ & Internal & Defender & $\begin{array}{l}\text { Desing with the fishermen (and ensuring project } \\
\text { execution) }\end{array}$ & $\begin{array}{l}\text { Greater degree of communicastion ensuring that their role of the } \\
\text { ishermen is taken into account }\end{array}$ \\
\hline 4 & $\begin{array}{c}\text { Director of } \\
\text { Medterranean } \\
\text { projects }\end{array}$ & Chelonia & Valencia & Project member & $\begin{array}{l}\text { The successful erecution and testing of } \\
\text { TED device, as well as the successtul } \\
\text { complefion of the project. }\end{array}$ & Internal & Detender & Dealing with the fishermen & $\begin{array}{l}\text { Grester dogres of communicstion ensurng that theirole of the } \\
\text { fishermen is taken irto account }\end{array}$ \\
\hline 5 & Social Meda & Chelonia & Valencia & Project member & $\begin{array}{l}\text { The successful erecuton and testing of } \\
\text { TED device, as well ss the successful } \\
\text { complefion of the project. }\end{array}$ & Internal & Defender & $\begin{array}{l}\text { Really no drect problems - Just ensuring that the } \\
\text { Social Meda portray a positive image of Chelonia }\end{array}$ & No solution needed \\
\hline 6 & $\begin{array}{c}\text { Animal behariour } \\
\text { professor }\end{array}$ & $\begin{array}{l}\text { Universidad Autonoma de } \\
\text { Madrid }\end{array}$ & Madrid & $\begin{array}{l}\text { Project collaboritor } \\
\text { (Associated erpert } \\
\text { ressearcher) }\end{array}$ & $\begin{array}{l}\text { The successful erecution and testing of } \\
\text { TED device, as well as the successful } \\
\text { completion of the rojoect. }\end{array}$ & Internal & Defender & Collaboration of the fishermen & $\begin{array}{l}\text { Greater degree of communication ensuring that theirde of the } \\
\text { fishermen is token irto account }\end{array}$ \\
\hline 7 & Prodessor & $\begin{array}{c}\text { Universidad Compluterse de } \\
\text { Mastrid }\end{array}$ & Madrid & $\begin{array}{l}\text { Project collaborator } \\
\text { (Assocized expert } \\
\text { researcher) }\end{array}$ & The successful ereccution at the project. & Internal & Defender & $\begin{array}{l}\text { No real problem withr regards to this stakeholder as } \\
\text { there is no direct relationship between her and the } \\
\text { project }\end{array}$ & No solution needed \\
\hline 8 & Protessor & Universidad de Valencia & Valencia & Project colaborator & 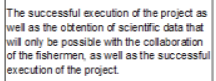 & Internal & Defender & Collaboration of the fishermento access dita & $\begin{array}{l}\text { Greater degree of communication ensuring that their role of the } \\
\text { ishermen is taken irto account }\end{array}$ \\
\hline 9 & President of NGO & СЕМMA & Galicia & External researcher & 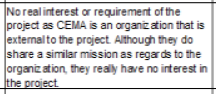 & Externa & Detender & $\begin{array}{l}\text { No real problem with regards to this stakeholder as } \\
\text { there is no direct relabionship between her and the } \\
\text { priject }\end{array}$ & No solution needed \\
\hline 10 & President of NGO & Xabc & Valencia & Project & 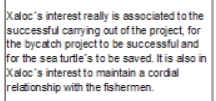 & Internal & Defender & Project tunding and fishermen colaboration & $\begin{array}{l}\text { Greater degree of communication ensuring that their roie of the } \\
\text { fishermen is taken irto account }\end{array}$ \\
\hline 11 & Scientific technician & Generatata de Valencia & Valencia & Project collaboritor & $\begin{array}{l}\text { The successful erecution of the projedt } \\
\text { weth the successeut testing of the TEDs } \\
\text { with the collaboration of the fishermen, and } \\
\text { there resultingly sasing of the marine } \\
\text { turtles. }\end{array}$ & Internal & Defender & $\begin{array}{l}\text { Stakeholder collaboration - Ensuring that this is a } \\
\text { realty and that there is collaboration from the } \\
\text { fishermen. }\end{array}$ & $\begin{array}{l}\text { Greater communcation and col aboration between al project } \\
\text { stakeholders and this wil onl be achieved through the increase and } \\
\text { improvement of cormunication between them. }\end{array}$ \\
\hline 12 & $\begin{array}{c}\text { Presidert d f fsting } \\
\text { association }\end{array}$ & Coffradia de Gandia & Gandia & Project collaborator & 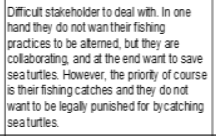 & Internal & Defender & $\begin{array}{l}\text { Representitation - Their tue protagonism being taken } \\
\text { into account and considered. }\end{array}$ & 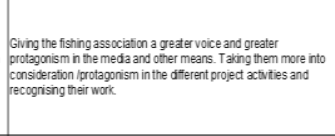 \\
\hline 13 & Researcher & Universidad de Valencia & Valencia & Project collaborator & $\begin{array}{l}\text { The successful execution of the project as } \\
\text { well as the ottertion of sciertific datathat } \\
\text { will only be possible with the collabortion } \\
\text { of the fishermen, as wel as the successtul } \\
\text { execution of the project. }\end{array}$ & Internal & Defender & Collabordion of the fishermen to access data & $\begin{array}{l}\text { Greater degree of communication ensuring that thei role of the } \\
\text { fishermen is taken into account }\end{array}$ \\
\hline 14 & $\begin{array}{l}\text { Predoctoral } \\
\text { researcher }\end{array}$ & Universidad de Valencia & Valencia & $\begin{array}{c}\begin{array}{c}\text { Project collaborator and } \\
\text { volurteer }\end{array}\end{array}$ & $\begin{array}{l}\text { The successful execution of the project as } \\
\text { well as the ottertion of scientific datathat } \\
\text { will only be possibla with the collabordion } \\
\text { of the fishermen, as wel as the successful| } \\
\text { execution of the project. }\end{array}$ & Internal & Defender & Collaboration of the fishermen to access data & $\begin{array}{l}\text { Greater degree of communic ation ensuring that thei role of the } \\
\text { ishermen is taken into account }\end{array}$ \\
\hline 15 & $\begin{array}{l}\text { Predoctoral } \\
\text { researcher }\end{array}$ & Universidad de Valencia & Valencia & $\begin{array}{l}\begin{array}{l}\text { Project collaborator and } \\
\text { volurteer }\end{array}\end{array}$ & $\begin{array}{l}\text { The successful execution of the project as } \\
\text { well as the ottertion of sciertificic datathat } \\
\text { will only be possible with the collabordicn } \\
\text { of the fifhermen, as wel as the successful } \\
\text { evecution of the project. }\end{array}$ & Internal & Defender & Collabordion of the fishermen to access data & $\begin{array}{l}\text { Greater degree of communication ensuring that thei role of the } \\
\text { ishermen is taken into account }\end{array}$ \\
\hline 16 & $\begin{array}{l}\text { Professor and } \\
\text { researcher }\end{array}$ & $\begin{array}{l}\text { Universidad Cáôilica de } \\
\text { Valencia }\end{array}$ & Valencia & External researcher & 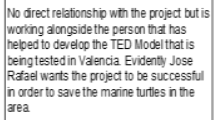 & External & Defender & $\begin{array}{l}\text { No real problem with regards to this stakeholder as } \\
\text { There is no direct relationship between her and the } \\
\text { project }\end{array}$ & No solutionneeded \\
\hline 17 & Sciertific consuliant & t Secretaria General de Pesca & Madrid & $\begin{array}{l}\text { Extenal project } \\
\text { supporter }\end{array}$ & $\begin{array}{l}\text { The successful execution of the project all } \\
\text { in favor of the conservation of the marine } \\
\text { turltes and prodected maine areas. }\end{array}$ & Extemal & Defender & $\begin{array}{l}\text { No real problem with regards to this stakeholder as } \\
\text { there is no direct relationship between her and the } \\
\text { project Ensurng that the project is carried out in a } \\
\text { legal ethical manner. }\end{array}$ & $\begin{array}{l}\text { Noreal solution is needed here as the role of the S.G Pesca is more } \\
\text { legal than anything, athough they may be of some help with regard to } \\
\text { getting the support of the fishermen. }\end{array}$ \\
\hline 18 & Volunteer & Chelonia & Hueva & Projectvolunteer & $\begin{array}{l}\text { The successful execution and testing of } \\
\text { TED derice, as well as the successful } \\
\text { completion of the project }\end{array}$ & Internal & Defender & Project funding and fishermen collaboration & $\begin{array}{l}\text { Greater degree of communication ensuring that thei role of the } \\
\text { fishermen is taken into account }\end{array}$ \\
\hline 19 & Prodessor & CEU & Valencia & Project volunteer & $\begin{array}{l}\text { The successful execution and testing of } \\
\text { TED device, as well as the successfil } \\
\text { completion of the project. }\end{array}$ & $\begin{array}{c}\text { InternavExt } \\
\text { ernal }\end{array}$ & Defender & $\begin{array}{l}\text { No real problem with regards to this stakeholder as } \\
\text { there is no direct relationship between her and the } \\
\text { groject }\end{array}$ & No solutionneeded \\
\hline 20 & $\begin{array}{c}\text { Entrepreneur and } \\
\text { professor }\end{array}$ & EAE Business School & Madrid & Extemal & $\begin{array}{l}\text { No real irterest in the project but in farour } \\
\text { of marne turtle conservation. }\end{array}$ & External & Defender & $\begin{array}{l}\text { No real problem with regards to this stakeholder as } \\
\text { there is no direct relationship between her and the } \\
\text { project }\end{array}$ & No solutionneeded \\
\hline 21 & $\begin{array}{c}\text { Represertititive of } \\
\text { ICUN (Specify } \\
\text { specfic role) }\end{array}$ & IUCN & Malaga & Extemal & $\begin{array}{l}\text { Successtul project execution to beneft the } \\
\text { marne turles }\end{array}$ & External & Defender & $\begin{array}{l}\text { No real problem as regards to the project. is a } \\
\text { supporter of the al project activites. The UCN } \\
\text { basicaly estabishes the conservation status of the } \\
\text { marne turles. }\end{array}$ & No solutionneeded \\
\hline
\end{tabular}


Furthermore, the information compiled in the stakeholder register was further analysed via the development of a stakeholder map for the project shown below in Figure 1, where project defenders were characterised by stars and project opponents by hexagons. Although some of the trends extracted from the stakeholder map are described further in the Discussion section below, it is possible to observe that most of the interviewed stakeholder groups supported the project mission. These relationships/associations between the different stakeholders are important.

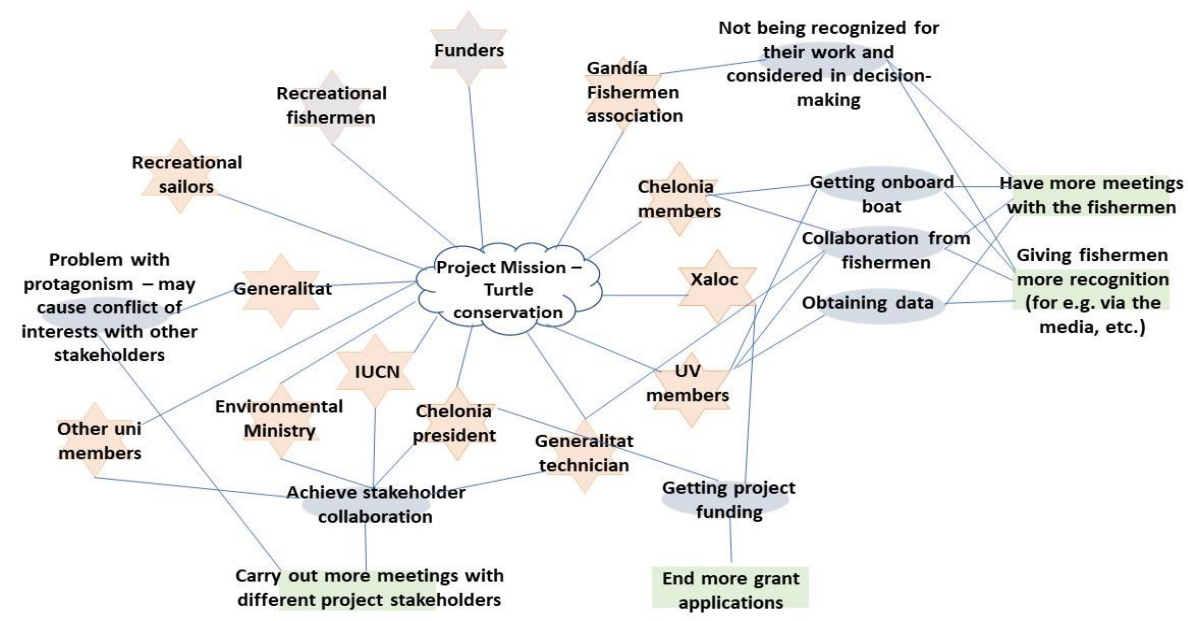

Figure 1: Stakeholder map of marine turtle bycatch project

The perspectives of the different stakeholder groups interviewed were compiled so that trends could be extrapolated on how the different groups evaluated the respective power and interest levels of the project stakeholder groups in relation with 
the project mission, which is reduction of marine turtle bycatch (i.e., thereby supporting marine turtle conservation).

All of the interviewees were asked to develop PI matrices. The only perspective that was not analysed in the PI matrices was that of the Gandía fishermen's association, as its president did not consider that he had the knowledge to carry out the exercise. Therefore, the groups whose perspectives are represented are:

- Chelonia members

- The NGOs

- $\quad$ The universities

- The regional government

- The national government

- The University of Valencia researchers

An extensive cross-analysis of the PI matrices was carried out for the above stakeholder groups. These results have already previously been published by the author in an article titled, "Revitalizing the Global Alliances for Sustainable Development: Analysing the Viability of Sustainable Development Goal 17-A MultiActor Governance Approach" that was published in the Journal of Sustainability this year.

The interviewees were also asked to evaluate the level of power and interest of the marine turtle in the project, along with the position of the other stakeholders as may be seen in Figure 2, that shows the perspective of Valencia's regional environmental representative. 


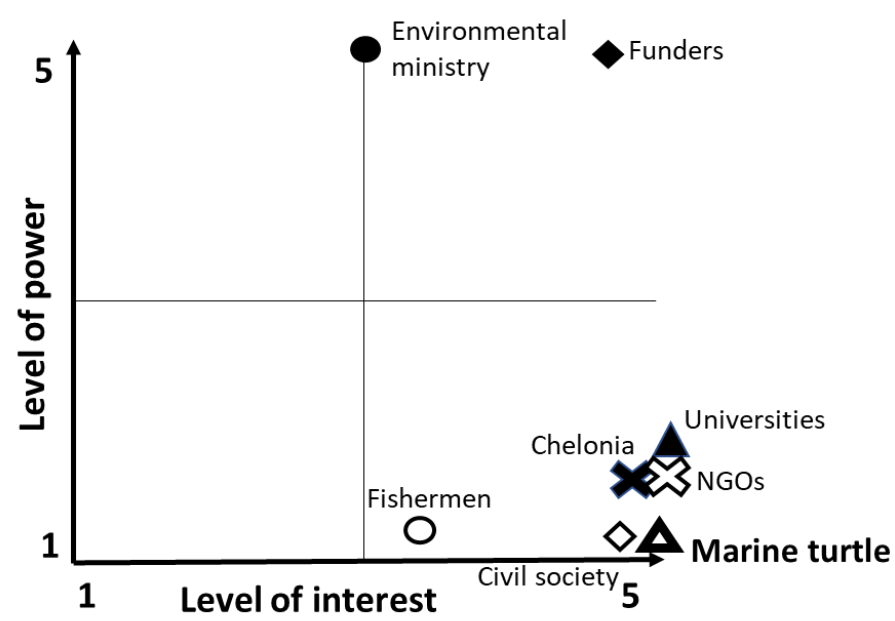

Figure 2: Perspective of the regional government environmental representative regarding the different project stakeholders (i.e., including marine turtle).

The information gathered simply concerning the role of the marine turtle is reflected in Figure 3, where it is possible to observe how Chelonia members, the regional governments as well as the other NGOs and universities viewed the role of the marine turtle in the project. 


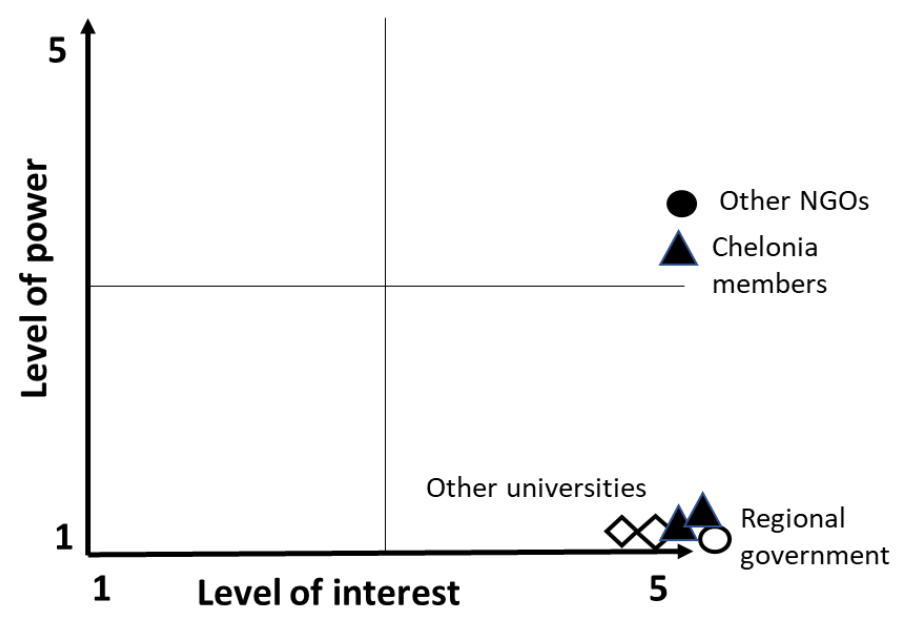

Figure 3: Perspective of different interviewee groups on how they perceived the role of the marine turtle in the project.

As we can see in Figure 3, all of the interviewees (NGOs, universities and regional authorities) considered that the marine turtles did have a high level of interest in the project, while perspectives were divided in regard to how much power they actually had in the project. Some Chelonia members and the other NGO Xaloc did perceive the marine turtles as having considerable power, while the rest of interviewees considered them to have no power.

The interviewees were also asked whether they considered that the marine turtle should be a project stakeholder in one of the interview questions. 16 out of the 20 respondents that answered this question said that they did think that the marine turtles should be considered to be stakeholders in projects. 


\section{DISCUSSION}

In the projects where non-human primordial stakeholders have a protagonist role, it is very important to be able to clearly define the status and the role of the non-human stakeholder, which is in this case the marine turtle. In the marine turtle bycatch project, the conservation of the marine turtle was the prime objective, being the marine turtle a threatened species. Reducing bycatch meant more effective marine turtle conservation in the Mediterranean. Figure 1 shows that all stakeholders interviewed supported the project. Moreover, they also had a common viewpoint of the concept of nature, which helped to clear a roadblock and align their mindsets with regard to the project mission ${ }^{84}$. As shown in Bulmer and Del Prado-Higueras' (2021) article, this alignment of perspectives from the different stakeholders ensured a better project realization. However, could the latter perhaps be improved should the primordial nonhuman stakeholder of the project, the marine turtles, be included in the stakeholder map? At present there is still some reluctance from academics with regard to this notion. Driscoll and Starik (2004: 55) argue that "while most stakeholder theories have progressed to the point in which the natural environment is given stakeholder status, some academics continue to be reluctant to include the natural environment as one of the...primary stakeholders" ${ }^{85}$. Furthermore, reluctance has been demonstrated by corporations that tend to overlook the importance of the environment as a stakeholder and consequently to place it low on the stakeholder list ${ }^{86} 8788$.

The main problem with the notion of extending the current project stakeholder management theory so to include nonhuman actors is that it can be controversial

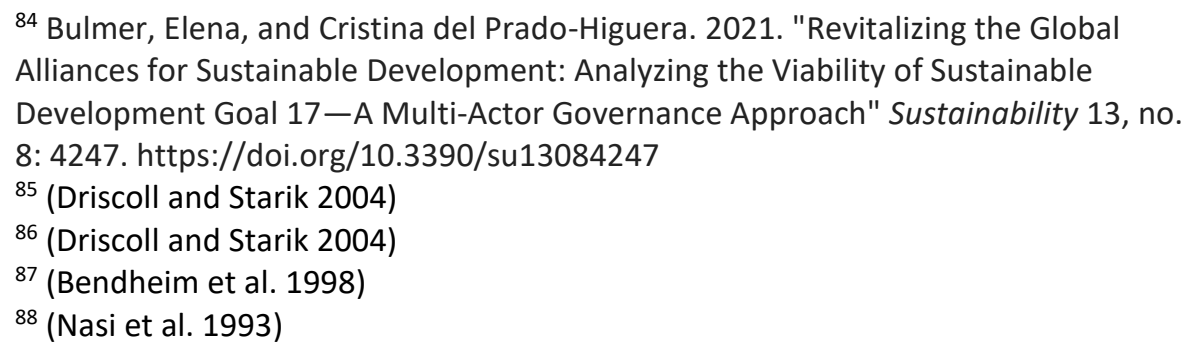


considering the fact that such actors are unable to express themselves verbally, and therefore are unable to communicate how they feel and think. It is therefore essential to find a way in the particular project studied to best represent the turtles so that their position will be taken into account. A way to do the latter may be to have a specific project stakeholder (person or group of people) to represent the Valencian marine turtles. In this respect, one might perhaps think that the scientists are the best marine turtle representatives due to all of the scientific information they possess and handle. However, couldn't the fishermen also have this role as they spend most of their time at sea?

In this study, the scientists were probably the best interlocutors to account for the role of the marine turtles in the project, as their stance was based on rigid scientific experimentation and observation. When drawing up the conservation regulations for the protection of the marine turtles at a national or European level, authorities have usually based their reasoning and decision making strictly on scientific experimentation and observation. One of the trusted information sources is the International Union for the Conservation of Nature that derives its knowledge from a compendium of scientific sources of experts that specialize in the observation and conservation of marine turtles. This type of scientific information is often sent to the governmental authorities for the development and implementation of the different conservation laws. In Spain the enactment of biodiversity conservation laws by the Spanish Environmental Ministry (i.e., Ministerio para la Transición Ecológica y el Reto Demográfico - Ministry for the Ecological Transition and the Demographic Challenge) is based on mainly the scientific data provided by a pool of universities, scientific NGOs, Public companies, research centres and a few private companies (i.e., that work on the development of technology and tools needed for the empirical work of conservation biology). Some of the latter will be describe heron:

- Universities: There are several universities working on marine turtle conservation in Spain at the moment. Among them are the University of Valencia, the Autónoma University of Madrid, and the Complutense University. 
- Research centres: The research centres may be based at universities. But in Spain there is the CSIC - Consejo Superior de Investigaciones Científicas (Superior Council of Scientific Research), whose mission is to promote, coordinate, develop and disseminate multidisciplinary scientific and technological research at all levels. Among the different centres ascribed to the CSIC is the Natural History Museum in Madrid that also works on biodiversity conservation ${ }^{89}$.

- Public companies: These companies are funded with public money. Examples include companies like Tragsa and Tragsatec, which provide sustainable solutions to the Public Administration with regard to environmental, rural development and resource management issues ${ }^{90}$

In the case study analysed, the fishermen interviewed complained that they weren't really considered by the different authorities when laws were being enacted. Even through most project stakeholders were found to engage cooperatively throughout the project's execution (Figure 1), the fishermen were those most challenging to deal with. Initially, the scientists (i.e., from universities and NGOs) experienced considerable difficulty in obtaining the collaboration of the fishermen, especially at the beginning of the project, when they tried to get onboard the fishing vessels to and obtain scientific data. According to the fishermen, the scientists were distanced from the reality of the fishermen working for a living and just came aboard to obtain their data. In our study even one of the University of Valencia's scientists recognized the importance of the fishermen, "I think that the most important would be the fishing part. Everything that is related to fishing because, everything depends on the

${ }^{89}$ CSIC (2021 July 12 ${ }^{\text {th }}$ ) EI CSIC. https://www.csic.es/es/el-csic

90 Grupo Tragsa (2021 July 12th). Misión, Vision y Valores. https://www.tragsa.es/es/grupo-tragsa/quienes-somos/Paginas/misionvision-y-valores.aspx 
fishermen, on whether they want or not to collaborate" (University of Valencia researcher, Personal Communication, February 2019).

Through the analysis of the data compiled for this study, it was found that the fishermen were key players in their potential contribution of knowledge of everything that went on at sea. Fishermen rely on the sea for their living and are therefore always in touch with nature (the water, fish, marine turtles, and other species). They may therefore possess information and perspectives that the scientists may not have (i.e., thereby becoming an essential source of information, should a global perspective need to be considered, especially to be able to provide "Sustainable" solutions for example to specific conservation issues).

The 2030 Agenda Accelerator that was developed by the UN Department of Economic and Social Affairs (UN DESA) and The Partnering Initiative in 2019 strive to "significantly help accelerate effective partnerships in support of the Sustainable Development Goals" [8]. A systemic perspective is therefore necessary to ensure the realization of the other SDGs as well as the development of laws to implement sustainability in an effective way. The question related to this study then is whether in pursuit of SDG 17, "Partnerships for the Goals", nonhuman actors should be ascribed the role of a stakeholder when that actor is in fact the object of the project's mission, such as for example to comply with SDGs 14 (Life below water) and 15 (Life on land)? Therefore, is it possible to manage a stakeholder whose process of identification and definition is rather subjective, especially when that stakeholder is the object of the study, but they however cannot express themselves (i.e., being a nonhuman subject) and their conservation is left in the hands of others?

As projects are executed, different social networks are created between the different project stakeholders (i.e., as shown in Figure 1). These social networks may become an impediment when trying to figure out the best way to manage this non-human primordial stakeholder because of these different interests, as it is possible that they will just create more noise and potentially obstruct the execution of the project 
objectives. In this study, most stakeholders were found to support the project mission and seemed to care about marine turtle conservation. However, there is a possibility that the various stakeholders may view the role of the nonhuman primordial stakeholder differently, something that might therefore restrict the project through the creation of boundaries in the project, thus inhibiting the development of a common stance among different project actors.

All interviewees in this study were asked whether the marine turtle should be considered to be a project stakeholder. The specific question asked in the interview was "For you, does it make sense to think of the turtles and/or fish as a stakeholder in a similar way to the other stakeholders mentioned?". The different project stakeholder perspectives were compiled and categorized. Below is a list of the different stakeholder perspectives regarding the nonhuman primordial actors of the Valencian bycatch project, which are the marine turtles and fish.

- The fishermen need to fish and earn their living; however, they do not want to harm the marine turtles in any way. Now in the Levante Coast, the fishermen have developed a series of initiatives to contribute towards their conservation.

- The scientists from the UV want to obtain data and protect sea turtles.

- Civil society really perceive the marine turtles as attractive animals to protect, however it really does not have a say in the marine bycatch project.

- $\quad$ Chelonia and Xaloc want to ensure that the TED pilot study works in order to protect sea turtles. Out of the two organizations, Xaloc is the one that is more involved in creating awareness.

- $\quad$ Financing bodies want the successful execution of the project they are funding and for the project holding organizations to be correct and punctual as regard to the generation of reports and other project documentation. 
The inclusion of nonhuman actors in the stakeholder map is important. As regard to the natural environment, failure to include the natural environment as a project stakeholder may often lead to considerable monetary losses, as for example for an agriculture-based business should there be a serious drought or where the depletion of fish in the fishing industry may lead to serious financial losses ${ }^{91}$. After all, firms do depend on local ecosystems (i.e., raw materials) for their survival and the development of their products ${ }^{9293}$.

In addition to avoiding or reducing monetary losses, the inclusion of these primordial stakeholders in the project stakeholder map will also promote their conservation. An example of this is a river otter case study in Missouri, USA. In this example, Missouri's Department of Conservation (DOC) wanted to reintroduce the river otter and did so; however, as the species began reproducing, conflicts started to arise between the DOC, the local residents, the animal activists and the scientists ${ }^{94}$. As nonhuman primordial stakeholders, the river otters in this project were not able to express themselves so as to have their say in the project. Their inclusion in the project as primordial stakeholders was key for the project to achieve a successful outcome. This kind of case study thus raises the question as to how these nonhuman environmental stakeholders may be taken into account and represented in a project. For these stakeholders, the "stakes are only relevant when they are inserted into a process where they influence the courses of action in the project"95.

The presence of primordial environmental nonhuman stakeholders, such as ecosystems, in the stakeholder maps of more business and management-oriented projects, should be more widespread. Moreover, there is also a present trend for many corporations to stress their awareness of and respect for the issue of sustainability and their Corporate Social Responsibility, thus obliging them to show

\footnotetext{
${ }^{91}$ (Driscoll and Starik 2004)

${ }^{92}$ (Gladwin et al. 1995)

${ }_{93}$ (Driscoll and Starik 2004)

${ }^{94}$ (Goedeke and Rikoon 2008)

95 (Tryggestad et al., 2013: 73)
} 
that they give back to the environment and therefore demonstrating how important ecosystems are to their operations and viability and therefore how such ecosystems are in reality the primordial stakeholders and how they should thus be represented as such on the project stakeholder maps. This is especially the case when these stakeholders are the project's primordial stakeholder. Examples of these in environmental conservation projects include Callon's (1986) scallop-restoration effort, and Goedke and Rikoon's 2008 river otters' narratives.

In this marine turtle study, there was an intermediary party who "centralized" all of the information and linked all parties thereby filtering the different stakeholder interests and needs. Juan Eymar, the Generalitat's environmental representative, played a protagonist role in getting the project stakeholders to collaborate and work together toward the conservation of the Levante Coast marine turtles. Through his charisma and empathy, Juan was able to get stakeholder collaboration from all parties. In the marine turtle project, he facilitated access for Chelonia and the scientists to the fishermen and fishermen's associations. Juan's active participation with the fishermen over the past 26 years, has brought the result of ensuring the fishermen's participation in the project, and has brought many parties together and over time created a strong multidisciplinary collaboration between the different project stakeholders; universities, NGOs and local governments.

The 2030 Agenda Accelerator strives to promote the development of global alliances (SDG 17) to be able to achieve more efficiently the other sixteen Sustainable Development Goals. Collaboration and establishing a sufficient degree of common ground between the different project stakeholders is therefore essential. The inclusion of nonhuman actors in the development of these global alliances is perhaps something that should be considered. How this should be done exactly is yet to be determined, however from this study, what is clear is that it is bound to bring added value. When considering the inclusion of a nonhuman stakeholder, the exact nature of the project and its context become of prime importance for the determination of how exactly to designate the necessarily human delegate(s) or human agency most 
apt to best represent the nonhuman actor(s) concerned. To date, in environmental conservation projects, scientific data is the basis for the enactment of conservation laws, however, as was noted in this study, qualitative data from the fishermen could also contribute significantly towards marine turtle conservation in Valencia, Spain. Who should therefore represent the marine turtles, solely the scientists or also the fishermen?

Then comes the question as to whether is it possible to manage a stakeholder whose process of identification and definition is rather subjective, especially when taking into account that this stakeholder in question has evident protagonism as it is the object of the conservation project itself but doesn't have a voice as such and is not able to express itself (being a non-social subject), and whose conservation is based on the perceptions of others?

\section{CONCLUSION}

This case study opens the possibility for nonhuman actors like the marine turtle in this case study to be included in the project's stakeholder map. Therefore, the research question to be asked is whether the current project stakeholder definition ${ }^{96}$ should be extended so to include nonhuman stakeholders such as the natural environment. This would be a "radical extension to Freeman's definition" 97 but which is almost certainly needed as a corporation's business objectives can be considerably affected by the natural environment, such as for example by the depletion of natural resources. Consequently, failure to include the natural environment as a project stakeholder may often lead to marked monetary losses, as for example for an agriculture-based business should there be a serious drought or where the depletion of fish in the fishing industry may lead to serious financial

\footnotetext{
${ }^{96}$ (Freeman 1984)

97 (Winch 2016)
} 
losses ${ }^{98}$. After all, firms do depend on local ecosystems (i.e., raw materials) for their survival and the development of their products ${ }^{99} 100$.

In this study, which analyses a marine turtle bycatch reduction project in Valencia (Spain), we have evaluated the potential inclusion of a nonhuman actor, the marine turtle, in the project's stakeholder map. Through the interview questions, it was found that most respondents had a similar perspective of nature and the project mission. This helped to align the project stakeholders in support of the project's mission. Interviewees were also asked whether the marine turtle should be considered to be a project stakeholder. Out of the 21 people interviewed, 16 said that they considered that the marine turtle should be considered to be a project stakeholder.

The question can be asked as to whether it is possible to manage a stakeholder whose process of identification and definition is rather subjective, especially when taking into account that this stakeholder in question has evident protagonism as it is the object of the conservation project itself but doesn't have a voice as such and is not able to express itself (being a non-social subject), and whose conservation status is based on the perceptions of others?

The types of projects that deal with natural environmental phenomena (species and ecosystems) as their primordial stakeholders include construction projects, engineering projects, environmental conservation projects, etc. In environmental conservation projects, the species and ecosystems themselves are in most cases the object of conservation (i.e., and the project's nonhuman primordial stakeholders). Their inclusion in the actor network map is essential as doing so will therefore ensure that the best conservation strategy is found for them. This study is just one example of how the inclusion of a nonhuman actor in the stakeholder map may contribute to the successful execution of a project, in this instance an environmental conservation project. The question related to this study is whether in

\footnotetext{
98 (Driscoll and Starik 2004)

${ }^{99}$ (Gladwin et al. 1995)

100 (Driscoll and Starik 2004)
}

Attribution-NonCommercial 4.0 International (CC BY-NC 4.0). 
pursuit of SDG 17, "Partnerships for the Goals", nonhuman actors should be ascribed the role of a stakeholder when that actor is in fact the object of the project's mission, such as for example to comply with SDGs 14 and 15.

\section{BIBLIOGRAPHY}

Bendheim, C.L., Waddock, S.A. \& Graves, S.B. (1998). Determining Best Practice in Corporate Stakeholder Relations Using Data, Envelopment Analysis. Business and Society 37(3), 306-448.

Callon, M. Some elements of a sociology translation: domestication of the scallops and fishermen of St Brieuc Bay". In: Law, J. Power, Action and Belief: A -New Sociology of Knowledge. London, United Kingdom: Routledge \& Kegan Paul; 1986. pp. 277-303.

Callon, M., Latour, B. Unscrewing the big Levathan: how actors macrostructure reality and how sociologists help them to do so. In: Knorr-Cetina, K., Cicourel, V. Advances in social theory and methodology: towards an integration of micro- and macro- sociologies. Boston, United States: Routledge \& Kegan Paul; 1981.

CSIC (2021 July 12th) EI CSIC. https://www.csic.es/es/el-csiC

Driscoll, C. \& Starik, M. (2004). The Primordial Stakeholder: Advancing the Conceptual Consideration of Stakeholder Status for the Natural Environment. Journal of Business Ethics, 49:55-73.

Freeman, R.E. (1984). Strategic Management: A Stakeholder Approach. Cambridge, CUP.

Gladwin, T.N., Kennelly, J.K. \& Krause, T.S. (1995). Shifting Paradigms for Sustainable Development: Implications for Management Theory and Practice. Academy of Management Review, 20(4): 874-907. 
Goedeke, T.L. \& Rikoon, S. (2008). Scientific Controversy, Dynamism of Networks, and the implications of Power in Ecological Restoration. Social Studies of Science 38(1): 111-132.

Grupo Tragsa (2021 July 12th). Misión, Vision y Valores. https://www.tragsa.es/es/grupo-tragsa/quienes-somos/Paginas/mision-vision-yvalores.aspx

IUCN. About International Union for Conservation of Nature. Available from: https://www.iucn.org/about (Accessed on 1 March 2021)

Missioner, S., Loufrani-Fedida, S. Stakeholder analysis and engagement in projects: From stakeholder relational perspective to stakeholder relational ontology. International Journal of Project Management, 2014; 32: 1108-1122.

Nasi, J., Nasi, S., Philips, N. \& Zyglidopoulos, S. (1993). "What is Stakeholder Thinking? A Snapshot of a Social Theory of the Firm", in J. Nasi (ed), Understanding Stakeholder Thinking. Helsinki, LSR-Julkaisut Oy, 19-32.

PMI, 2017

Revitalizing the Global Alliances for Sustainable Development: Analyzing the Viability of Sustainable Development Goal 17-A Multi-Actor Governance Approach

Sach, JD. From Millennium Development Goals to Sustainable Development Goals. The Lancet, 2012; 379 (9832): 2006-2211.

Stead, J.C. \& Stead, W.E. (2000). Ecoenterprise Strategy: Standing for Sustainability. Journal of Business Ethics, 24(4): 313-329.

Tryggestad, K., Justesen, L. \& J. Mouritsen. (2013). Project temporalities: how frogs can become stakeholders. International Journal of Managing Projects in Business 6(1): 69-87.

United Nations (2021 March 1). 17 Goals to Transform our World. https://www.un.org/sustainabledevelopment/ 
Winch, G. (2010). Managing construction projects. Blackwell Publishing Ltd. lowa, USA.

Winch, G. (2016). "Megaproject Stakeholder Management" in The Oxford Handbook of Mega-project Management (Ed. Bent Flyvbjerg). Oxford: Oxford University Press. 
